\title{
The Effect Of Transformational Leadership, Work Environment, Job Satisfaction To Employees Performance
}

\author{
Era Dwi Setyaningsih ${ }^{1}$, Rojuaniah ${ }^{2}$ \\ Esa Unggul University Jakarta, Indonesia ${ }^{1,2}$
}

\begin{abstract}
This research aims to analyze the effect of transformational leadership style and work environment to employees performance through job satisfaction as an intervening variable at Yayasan Matahati Nabawi. This study is Descriptif and Verifikatif research. Population on this research are employees that work at Yayasan Matahati Nabawi. and the sampling method that used in this research is kuesioner with 67 respondent. Data analysis that used Partial Least Square analysis (PLS). Result of this research are there is the effect of transformational leadership to job satisfaction at Yayasan Matahati Nabawi, there is not the effect of work environment to job satisfaction at Yayasan Matahati Nabawi. there is the effect of transformational leadership to employees performance at Yayasan Matahati Nabawi, there is the effect of work environment to employees performance at Yayasan Matahati Nabawi, there is the effect of job satisfaction to employees performance at Yayasan Matahati Nabawi, there is the effect of transformational leadership to employees performance through job satisfaction at Yayasan Matahati Nabawi, there is the effect of work environment to employees performance through job satisfaction at Yayasan Matahati Nabawi.
\end{abstract}

Keywords: Transformational Leadership, Job Satisfaction, Employees Performance and Work Environment

\section{INTRODUCTION}

With the rapid development of business environment that occurs in the era of globalization, companies are required to adapt well in order to compete with other companies. The success of a company or organization is determined by the existence of human resources owned. Human resources in this case are employees. Employees become one important asset for a company, because with the presence of competent employees will bring the company to achieve its goals. Competence is an aspect of a person's ability that includes knowledge, skills, attitudes, values or personal characteristics that enable workers to achieve success in completing their work through achievement of results or success in completing tasks. Effective leaders are leaders who have the ability to influence the behavior of their members and direct their subordinates to achieve the company's goals. Therefore, the right leadership style is needed in the company. Leaders can influence morale, job satisfaction, security, quality of work life and especially the level of achievement of an organization. The quality of the leader is often regarded as the most important factor of organizational success or failure as well as the success or failure of a business-or business-oriented organization, usually perceived as a leader's success or failure. Applying the right leadership will give the final result of performance improvement, this is in accordance with some research results that examine the relationship between transformational leadership and performance. Transformational leadership has a sense of leadership that aims for change. A transformational leader can bring about great change in both a follower and an organization. Not only leadership to note, but a comfortable working environment to be considered. According to Nitisemito (2002) the working environment of everything that exists around the workers and can influence him in carrying out the tasks that are embedded. Work environment is divided into physical work environment and psychic work environment. According to (Ginanjar, 2012) working environment conditions are said to be good or appropriate if humans can carry out activities optimally, healthy, safe, and comfortable. According to Doelhadi (2011), the work environment is an important factor and affect the employee in doing his job. Employees are very concerned with the work environment both for personal convenience and to facilitate the task well. Enjoyable work environment, such as clean office environment, adequate lighting, adequate ventilation, harmonious employee relations, good leadership, and so on, will create a feeling of satisfaction with employees, so employees will feel at ease and eager in completing the job. The organization should make sure that its employees can have positive views on their work environment, because the work environment is very influential in the work done. Handoko (2011) states that job satisfaction is a pleasant or unpleasant emotional state by which employees view their work. Satisfaction is created from the perception of employees in feeling satisfied or not satisfied with the results received from what they have done. High job satisfaction will encourage employees to work better. A person who has high job satisfaction will produce good performance for the company. Mangkunegara (2011) states that performance is the result of quality and quantity achieved by an employee in performing its duties in 


\section{International Advanced Research Journal in Science, Engineering and Technology \\ ISO 3297:2007 Certified \\ Vol. 5, Issue 8, August 2018}

accordance with the responsibilities it provides. Employee performance becomes the determinant of the company in achieving its objectives. If the employee's performance is good then the company will achieve the best result. Based on the background that has been proposed then the problem formulation in this research are (1) Is there any influence between transformational leadership on job satisfaction ?; (2) Is there any influence between work environment on job satisfaction ?; (3) Is there any influence of job satisfaction on employee performance ?; (4) Is there any effect of transformational leadership on employee performance ?; (5) Is there a work environment impact on employee performance ?; (6) Is there any effect of transformational leadership on employee performance through job satisfaction ?; (7) Is there a work environment influence on employee performance through job satisfaction?

\section{HYPOTHESIS DEVELOPMENT}

The Influence of Transformational Leadership to Job Satisfaction: According to Yulk (1998), transformational leadership affects job satisfaction and subordinate satisfaction with the leader. Relationship between job satisfaction with the behaviors of transformational leaders is caused because one aspect of job satisfaction is supervision. Supervision provided by leaders through individual attention, and inspirational motivation will enable subordinates to do good work.

The results of Amin \& Khan (2013) states that transformational leadership and transactional leadership, especially in the contingent rewards dimension, will increase job satisfaction, while authoritative and laissez-faire leadership can decrease job satisfaction. Based on the research of Negussie \& Demissie (2013) found that transformational leadership can increase job satisfaction. While the results of research Bateh (2013) states effective transformational leadership has increased job satisfaction.

Influence between Work Environment to Job Satisfaction: The correlation of the influence of work environment with job satisfaction is one factor of many other influencing factors, job satisfaction affect employee turnover and absenteeism, less conducive working environment can also affect low job satisfaction. Employees who are less attentive or uncomfortable with the work environment tend to be more often absent and leave the company and look for opportunities in other companies. (Handoko, 2000). Hayes, et.al. (2014) stated in his research that the work environment gives a very important influence for the development of job satisfaction.

Similarly research conducted by Bai, et.al. (2015) states that a healthy work environment is closely related to the level of job satisfaction. The results of Al-Hamdan, et.al. (2017), conveyed that more attention should be given to creating a positive work environment to improve job satisfaction and increase their intention to work longer. Leaders and workers and policymakers feel the need to create a satisfactory working environment that supports work practices to improve job satisfaction.

The Influence of Job Satisfaction on Employee Performance: According to Risambessy, et al. (2012) says that job satisfaction using the aspects of job indicators themselves, opportunities for promotion, supervision, rewards and peer support have a positive and significant impact on employee performance. According to research conducted by Arifin (2015) states that the higher the teacher job satisfaction, the higher the performance of teachers. If job satisfaction can be improved, it will encourage teachers to improve their performance. This implies that job satisfaction can improve performance by providing an assessment that matches the achievement of the work award. Job satisfaction, employee motivation and performance become one of the factors that determine the success of a strong and well-run organization (Mathis \& Jackson, 2006).

Job satisfaction has a positive effect on employee performance, as well as dissatisfaction will have a negative impact on performance. Abandonment, exit from work, protests are examples of the effects of dissatisfaction (Luthans, 2006). According Hasibuan (2014) job satisfaction is the key driver of morale, discipline, and achievement of employee performance in support of the realization of corporate objectives.

The Influence of Transformational Leadership on Employee Performance: Leadership is basically the process of influencing others. In addition, leadership also means the ability to influence, move, and direct an action on a person or group of people for a particular purpose. In an effort to influence a leader's leaders apply different styles in each situation. Research conducted by Walumbwa, et.al. (2008) states that transformational leadership is directly and indirectly related to employee performance.

Mamik (2010), stated that corporate leaders need to pay attention to the leadership style used in encouraging and directing their subordinates so that they can improve their performance better, so the quality of products produced by employees is also more qualified. Every company always expect the achievement of organizational goals, where to achieve it required an important role for employees. A qualified and capable employee with a result that matches the company's expectations is very profitable. In order for employees more enthusiastic in carrying out their work, then it is appropriate if the company pay attention to the attitude of leadership. One leadership style that is considered capable of 


\section{International Advanced Research Journal in Science, Engineering and Technology \\ ISO 3297:2007 Certified \\ Vol. 5, Issue 8, August 2018}

improving employee performance is a transformational leadership style. According Munawaroh (2011) suggests that transformational leadership is described as a leadership style that can generate or motivate employees, so that it can grow and achieve performance at a high level.

However, there are different results of research on the influence of transformational leadership on performance. Such research as conducted by Parr, et. al. (2013), yielding different findings, ie transformational leadership unrelated to employee performance. The difference in the results of this study is an underlying basis for re-examining the relationship between transformational leadership on employee performance. In addition there are previous studies that provide different findings, namely transformational leadership is not directly related to the performance of employees, but with the addition of variables mediation.

The Effect of Work Environment on Employee Performance: According Wiryawan (2009) stating that the performance is influenced by several factors namely external environmental factors and internal factors of the employees themselves. And according Siagian (2002), argued that employee performance is influenced by several factors namely salary, work environment, organizational culture, leadership and others. Based on research Dul \& Ceylan (2014) states that the work environment that supports the creativity of the company will be able to improve employee performance.

Hedlund, et al. (2010) in his research states that the work environment and performance have a very close correlation. The purpose of this research is to design and measure performance for improvement of work environment. According to Jayasuriya, et.al. (2014) stated in his research that there are influence factors in the work environment, such as organizational culture and climate to employee performance. Human resource policies to improve performance in their work environment will increase positive behavior and increase motivation. From the theory and research above drawn the conclusion that a conducive working environment will have a direct impact on its employees, especially in terms of completion of work provided. The influence of the work environment on employee performance means that employees will feel comfortable with the existing working environment conditions, if the environment conditions are in accordance with him and not feel disturbed when they work, so with the comfort they are motivated in work, this causes many jobs can well resolved so that their performance can be said either.

The Influence of Transformational Leadership on Employee Performance through Job Satisfaction. Malik, et.al. (2017), Leaders applying modern techniques prefer to adopt behaviors according to employee conformity, there must be a clear vision, and effective communication of transformational leadership to enhance organizational commitment after employee job satisfaction. Furthermore, job satisfaction and organizational effectiveness increase through transformational leadership potential and overall performance improvement as employee interest increases. Frazier (2013), in his research stated that there is a relationship between organizational leadership and organizational culture and organizational work satisfaction and performance so as to facilitate organizational success. Research conducted Morgan (2014), there is a significant relationship between leadership, job satisfaction and employee performance results. Similarly Brown's (2016) study, explains that between transformational leadership and employee job satisfaction play a role in determining employee performance.

Effect of Work Environment on Employee Performance through Job Satisfaction: Vermeeren, et.al. (2011), in the study showed that there is influence of job satisfaction on customer satisfaction. In organizations where employees are more satisfied with their work, customers are more likely to be satisfied with employee performance. In addition, findings indicate that a comfortable and conducive working environment affects employee job satisfaction.

In a study conducted $\mathrm{Wu}$ (2011) explained that the level of individual interaction and work environment employees have a positive correlation with the level of job satisfaction and improvement of employee performance. According to research conducted by Jayasuriya, et.al. (2012), states that a conducive working environment increases employee satisfaction and work climate so that it affects job satisfaction. Ashraf, et.al (2013), in his research states that the work environment increases employee satisfaction levels and work productivity more effectively. The work environment provides facilities to satisfy employee performance as expected, achieving targets, fast work, erasing mistakes, trusting, developing new ideas, work commitments, productivity and improving organizational performance.

Hypothesis Formulation: The formulation of the hypothesis is part of the step in a study. But note that not every study should formulate hypothetes. Hypothesis is a temporary answer to the formulation of research problems, where the formulation of research problems have been expressed in the form of statements (Sugiyono, 2009) as below:

$\mathrm{H}_{1}$ : The better the transformational leadership will be the higher employee job satisfaction.

$\mathrm{H}_{2}$ : A conducive working environment will improve employee job satisfaction

$\mathrm{H}_{3}$ : High job satisfaction will improve employee performance

$\mathrm{H}_{4}$ : Good transformational leadership will improve employee performance

$\mathrm{H}_{5}$ : A conducive working environment will improve employee performance 


\section{International Advanced Research Journal in Science, Engineering and Technology \\ ISO 3297:2007 Certified \\ Vol. 5, Issue 8, August 2018}

$\mathrm{H}_{6}$ : Good transformational leadership will improve employee performance through job satisfaction.

$\mathrm{H}_{7}$ : A conducive working environment improves employee performance through job satisfaction level

\section{METHODS OF THE RESEARCH}

Research design: According to Arikunto (2010), the research design is a plan or design made by researchers as ancar ancar activities to be implemented. The research design used is descriptive design of quantitative analytics that aims to describe the nature and characteristics of data - data or variables tested. In addition, the design of this study is used to describe and describe what it is about a particular variable, symptoms, circumstances or phenomena, so that in this study used to analyze the data obtained in depth with the hope can know the influence between independent variables to the dependent variable. In this case the variables to be tested are first independent variables (X1) Influence of Transformational Leadership, second independent variable (X2) Work Environment, third independent variable (X3) Job Satisfaction and dependent variable (Y) Employee Performance. This research also uses causal design (cause effect) which aims to analyze the relationship or the level of influence of independent variables on the dependent variable, is the relationship quite significant through regression test.

Measurement: The variable according to Sugiyono (2011) is an attribute or the nature or value of a person, object or activity that has certain variations applied by the researcher to be studied and then drawn the conclusion. Variables examined in this study there are 4 (four) variables, namely the influence of transformational leadership, work environment, job satisfaction and employee performance. Variables Influence of transformational leadership, work environment, and job satisfaction as independent variable (independent), independent variable according to Sugiyono (2011), is a variable that influence or become a change or the emergence of dependent variable (bound), and employee performance as a dependent variable. Dependent variable (bound) according to Sugiyono (2011), is a variable that is influenced by or which become due, because of the variable. The operational definitions of variables in this study are described as follows: (a) Transformational leadership, transformational leadership according to Avolio \& Bass in Merhaut (2000), has dimensions that explain how a transformational leader behaviors in performing his role as a leader. The dimension consists of (1). Idealized Influence (Attributed) / Charisma, (2). Idealized Influence (Behavior), (3). Inspirational Motivation, (4). Intellectual Stimulation and (5) Stimulation. Individual Attention, (6). Effectiveness, (7). Extra Effort / Extra-Effort, (8). Satisfaction; (b) The Work Environment, Work Environment according to Huddleston's (2015) study are as follows: (1) Communication and Employment Relations, (2) Effective Decision Making and Levels team cohesiveness to achieve optimal work, (3) Employee appreciation level of work result and good Guidance; (c) Job satisfaction, Job Satisfaction according to Issah's research (2013) are as follows: (1) Employment: Job Satisfaction and Work Variation, (2) Salary: Working salary with salary, Salary conformity with expectation, and Conformity of salary with life requirement ; (3) Promotion: Employment promotion opportunities for employees, Job suitability with employee capability, Job promotion provisions; (4) Supervision: Employee's attitude toward superior policy, employee's attitude toward superior ability, and employee's attitude toward superior attitude; (5) Coworkers: Coworkers who support each other, Employee attitudes toward colleagues, and Working with healthy competition; (d) Performance, Performance according to Hao's research, et.al. (2) Efficiency: Effective level and work efficiency (2018) are as follows: (1) Task: Level of work quality conformity with defined standard, Planning of work according to achievement targets, Employee work order level and Tidiness of employee work, (2) Efficiency: , Effective level and work efficiency, Level of conformity of work with target specified time, (3) Quality of work: Supports decision of employer, Employee Work ethic, Work discipline, Morale work. this is the teacher.

And the intended interview is a meeting of two people to exchange information and ideas through question and answer, so it can be constructed meaning in a particular topic (According to Esterberg translated by Sugiyono, 2013).

In answering these questions or statements, Likert scale is used as a form of level or level of importance. According Sugiyono (2013) Likert scale used to measure, attitude, opinions and perceptions of a person or a group of social phenomena that occur. The scale used in the questionnaire is the Likert scale with multilevel answers in five categories ranging from highly agreed assessments to highly disagreeable ratings.

Data Collection and Sample: Population is the whole subject of research (Arikunto, 2013). Meanwhile, according to Sugiyono (2012) states that the population is a generalization region consisting of objects or subjects that have certain qualities and characteristics set by researchers to be studied and then drawn conclusions. In this study the population used is all permanent teachers and contracts with a period of work over 1 (one) year working in the Foundation Matahati Nabawi with the number of 87 people.

The sample is the partial or representative of the population studied (Arikunto, 2013). In accordance with the analysis tool that will be used is PLS (Partial Least Square) is a method of data analysis based on the assumption of the sample should not be large, ie the number of samples less than 100, can be done analysis, and residual distribution. In this study the number of respondents taken as many as 67 teachers who have status as an employee or permanent employee and contract employee with working period over 1 (one) year in Yayasan Matahati Nabawi. 


\section{International Advanced Research Journal in Science, Engineering and Technology \\ ISO 3297:2007 Certified}

Vol. 5, Issue 8, August 2018

Data Analysis Method with Structural Equation Model (PLS): PLS (Partial Least Square) is a variance-based structural equation analysis (SEM) that can simultaneously perform testing of measurement models as well as structural model testing. Furthermore, Ghozali (2006) explains that PLS is a soft modeling analysis method because it does not assume the data should be of a certain scale measurement, which means the sample size can be small (under 100 samples). The fundamental difference between PLS which is a variance-based SEM with LISREL or Covarian-based AMOS is the purpose of its use. Compared to covariance based SEM (represented by AMOS, LISREL and EQS software) component-based PLS is able to avoid two major problems faced by SEM-based covariance ie inadmissible solution and factor indeterminacy (Tenenhaus et al., 2005).

\section{RESULT AND DISCUSSION}

In the early stages of the study, researchers conducted data collection for pre-test purposes by distributing questionnaires to 30 respondents in the research object that has met the criteria to be respondents from the study. The researchers conducted a pre-test to find out whether the filling instructions, question constructs and other important parts of the questionnaire could be understood and indeed accurately represent each of the variables tested. Pre-Test is also used to reduce potential problems generated from preliminary data collected using the help of statistical data processing software for validity and reliability tests, where results are used to evaluate the research questionnaires for subsequent dissemination in the field. In the pre-test test that includes the validity and reliability test, it is found that all indicator statements are valid and reliable, so that the research can be continued on the research results with respondents outside the respondents who have been used in the preliminary research. Includes gender, age, education level, income, and employment status. Profile of this respondent adjusted with relevance to research conducted. For more details can be seen in the picture below :

Barlett test of sphericity is performed to test whether there is a correlation between the variables. Kaiser Mesyer Olkin (KMO) is used to measure the adequacy of sampling. Small KMO values show that factor analysis can not be used, because the correlation between the pairs of variables can not be explained by other variables. If the KMO value is below 0.5 then factor analysis can not be used or accepted. The acceptable KMO values are values from 0.5 to 0.9 . KMO value below 0.5 then factor analysis is not acceptable. (Malhotra, 2004) Validation of each research indicator is done by anti-image matrix test. The expected MSA value is a minimum of 0.500 . Based on the table of KMO test results obtained values above 0,500 then factor analysis on the variable can be used or valid, while for indicators that have a value below 0,500 then the indicator can not be used or invalid. The conclusion of the validity test is that 77 indicators of the research are tested and valid so that it can be used for further research.

Assessment of assessment instruments in addition must be valid, also must be reliable. Therefore, reliable reliability test is used to know the accuracy of the questionnaire value, meaning that the research instrument when tested in the same group although at different times the result will be the same. Alpha Coefficient Cronbach (Ca) is the most common statistics used to test the reliability of a research instrument. A research instrument is indicated to have an adequate level of reliability if the cronbach alpha coefficient is greater than or equal to 0.60 (Dasgupta, 2013). From result of research got result all test to all instrument of research have reliable.

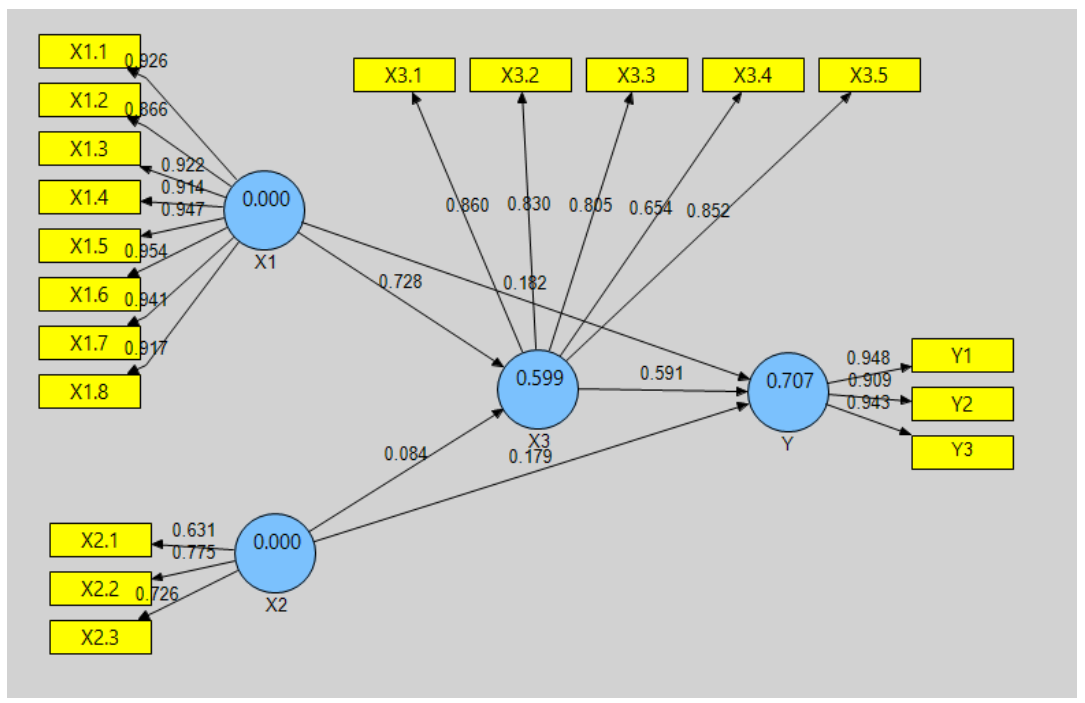

Figure 6: PLS Bootstrapping Results

Source: Data processing of research respondents, 2018 
Based on the above table, all indicators of each construct of Transformational Leadership (X1, Working Environment (X2), Job Satisfaction (X3), and Performance (Y) have a Loading Factor above above 0.5.It can be concluded that all indicators of the variable Transformational Leadership (X1, Work Environment (X2), Job Satisfaction (X3), and Performance (Y) are valid. The next check is to see the reliability of the construct with composite reliability. The value of composite reliability is said to be reliably if the value is above 0.6. Composite reliability results are shown in the table above where the value of composite reliability for each construct can be said to be reliable because the value is above 0.6. The next evaluation of convergent validity is an evaluation of the average value of variance extracted (AVE). Konstuk is said to have good convergent validity when the AVE value is above 0.5. The results of the table above show the value of AVE in each construct Transformational Leadership (X1, Work Environment (X2), Job Satisfaction (X3), and Performance (Y) above 0.5, so it can be concluded that the construct has a convergent validity good. Referring to Partial Least Square (PLS) method where respondent data is analyzed using structural model fit test. The complete relationship between variables in this study can be explained as follows:

Tabel 12: Path Coefficients (Mean, STDEV, T-Values)

\begin{tabular}{|l|l|l|l|l|l|}
\hline & $\begin{array}{l}\text { Original } \\
\text { Sample (O) }\end{array}$ & $\begin{array}{l}\text { Sample } \\
\text { Mean }(\mathbf{M})\end{array}$ & $\begin{array}{l}\text { Standard Deviation } \\
\text { (STDEV) }\end{array}$ & $\begin{array}{l}\text { Standard Error } \\
\text { (STERR) }\end{array}$ & $\begin{array}{l}\text { T Statistics } \\
(\mid \mathbf{O} / \text { STERR } \mid)\end{array}$ \\
\hline $\mathbf{X 1}$-> X3 & 0.728310 & 0.719783 & 0.061628 & 0.061628 & 11.817832 \\
\hline $\mathbf{X 2}$-> X3 & 0.084144 & 0.099914 & 0.095785 & 0.095785 & 0.878461 \\
\hline $\mathbf{X 3}$-> Y & 0.591229 & 0.592701 & 0.088826 & 0.088826 & 6.656029 \\
\hline $\mathbf{X 1}$-> Y & 0.181617 & 0.189619 & 0.091420 & 0.091420 & 1.986615 \\
\hline $\mathbf{X 2}$-> Y & 0.179080 & 0.173875 & 0.087516 & 0.087516 & 2.046245 \\
\hline
\end{tabular}

Source: Data processing of research respondents, 2018

Based on the above calculation, obtained t tcount is 0.861 . Because the value of $t$ arithmetic $(0.861)<t$ table $(1,96)$ then Ho accepted, meaning there is no significant influence of Work Environment (X2) on Performance (Y) through Job Satisfaction (X3). Hence the hypothesis H17 is unacceptable

\section{Direct and Indirect Influence}

Table 13: Direct and Indirect Influence

\begin{tabular}{|l|l|l|l|l|l|l|}
\hline \multirow{2}{*}{ Dimensions } & \multirow{2}{*}{$\begin{array}{l}\text { Path } \\
\text { Coefficient }\end{array}$} & \multirow{2}{*}{ Direct } & \multicolumn{3}{|l|}{ Indirect Influence } & Total \\
\cline { 4 - 6 } & & $\mathbf{X}_{\mathbf{1}}$ & $\mathbf{X}_{\mathbf{2}}$ & $\mathbf{X}_{\mathbf{3}}$ & Influence \\
\hline $\mathrm{X}_{1}>\mathrm{X}_{3}$ & 0,728 & 0,530 & - & - & - & 0,530 \\
\hline $\mathrm{X}_{2}>\mathrm{X}_{3}$ & 0,084 & 0,007 & - & - & - & 0,007 \\
\hline $\mathrm{X}_{1}>\mathrm{Y}$ & 0,182 & 0,033 & - & - & 0,430 & 0,463 \\
\hline $\mathrm{X}_{2}>\mathrm{Y}$ & 0,179 & 0,032 & - & - & 0,049 & 0,081 \\
\hline $\mathrm{X}_{3}>\mathrm{Y}$ & 0,591 & 0,350 & - & - & - & 0,350 \\
\hline
\end{tabular}

Source: Data processing of research respondents, 2018

From the table above can be seen that: 1). The total influence of Transformational Leadership (X1) on Job Satisfaction (X3) is 0,$530 ; 2$ ). Total influence of Work Environment (X2) on Job Satisfaction (X3) equal to 0,007; 3). Total influence of Transformational Leadership (X1) on Performance (Y) of 0.033; 4). Total influence of Work Environment (X2) on Performance (Y) of $0.032 ; 5)$. Total influence Job satisfaction (X3) on Performance (Y) of 0.350; 6). Total influence of Transformational Leadership (X1) on Performance (Y) through X3 of 0.463; 7). The total influence of Work Environment (X2) on Performance (Y) through X3 is 0,081. This research was conducted to examine the influence of transformational leadership, work environment and job satisfaction on employee performance of Matahati Nabawi Foundation. Independent variables used in this research are transformational leadership, work environment and job satisfaction. Employee performance as a dependent variable. The following is a discussion of each of the related variables in this study.

Research shows that there is an influence of work environment through job satisfaction on employee performance at Yayasan Matahati Nabawi. This proves that the existing work environment has been considered quite adequate by employees working at the Foundation Matahati Nabawi. The work environment provided has been able to assist employees in conducting their daily work processes in carrying out the duties and responsibilities of the company and serving the public interest. Work environment that can help the work of its employees will be very useful in the completion of work. Employees can perform activities well and cooperate among other employees in the workplace. 


\section{International Advanced Research Journal in Science, Engineering and Technology \\ ISO 3297:2007 Certified}

Vol. 5, Issue 8, August 2018

\section{CONCLUSIONS}

Based on the results of research that has been discussed in the discussion, it can be obtained the following conclusions: (1) Transformational leadership style significant effect on employee job satisfaction Yayasan Matahati Nabawi. This proves that the transformational leadership style in the organization will increase employee job satisfaction; (2) The working environment has no significant effect on job satisfaction of employee of Matahati Nabawi Foundation. This is because employees already feel comfortable working environment Matahati Nabawi Foundation; (3). Job satisfaction has a significant effect on employee performance of Matahati Nabawi Foundation. This proves that the job satisfaction that has been felt by employees in the work it will improve performance; (4) The transformational leadership style has a significant effect on the performance of the employees of Yayasan Matahati Nabawi. This proves that the transformational leadership style that directs and supports its employees in work will improve employee performance; (5) The work environment has a significant effect on the performance of the employees of Yayasan Matahati Nabawi. These conditions indicate that a conducive working environment can improve employee performance; (6) The transformational leadership style through job satisfaction affects the employee performance of Matahati Nabawi Foundation; (7) The working environment through job satisfaction affects the performance of the employees of Yayasan Matahati Nabawi.

Limitations of Research: This study has several limitations, one of which is the most fundamental is on the object of research where the researcher only focuses on one organizational institution as one place in the sampling and population. Where an organizational institution as a data collection place can not represent the overall variables in measuring and evaluating all similar organizational institutions within industrial zones in Indonesia.

Suggestion: Based on the above research results, it can be suggested as follows: (1) The leader of Matahati Nabawi Foundation should improve the existing leadership style by paying attention to good work, suitable, and in accordance with the wishes of employees and provide technical assistance so that employees are able to overcome the work existing technical office or field; (2) The Matahati Nabawi Foundation should promote a conducive working environment with mutual respect and mutual care, mutual encouragement, enthusiasm of employees from its saturation during the work process and provide enhanced focus on work. When the existing work is relatively overloaded then the existing work environment will be able to help employees more focused in completing tasks that have been given leadership and it will contribute to the good work, by obtaining a good work employees will feel satisfied; (3) Matahati Nabawi Foundation should continue to provide job satisfaction to employees with benefits given the company should also be a concern, to the provision of promotions in accordance with the desires and performance of work so as to stimulate employees to feel satisfied. And when employees feel satisfied it will be able to improve employee performance; (4) The leader of Yayasan Matahati Nabawi should improve employee performance by growing confidence his subordinates, considering the decisions made, convincing his subordinates to produce better work, always providing mentoring and coaching to his subordinates, leaders who are always thinking of dealing with old problems in new ways, voicing subordinates' opinions to higher leaders, leaders who always do more work than the company expects, and leaders who always work well for satisfactory work so that employee performance can be improved. This is done so that employee performance can achieve company goals and targets; (5) The Matahati Nabawi Foundation should improve the conducive working environment by being careful in making important decisions for the company, establishing good relationships among all employees, because with a conducive working environment, productivity and comfortable it will be able to improve employee performance; (6) The leader of Yayasan Matahati Nabawi should improve employee performance through job satisfaction by giving employee direction to work compete in a healthy, diligent and neat task to produce good performance because satisfied employees will improve employee performance ; (7) Matahati Nabawi Foundation should improve the work environment through job satisfaction of employees of Yayasan Matahati Nabawi by paying attention to important things to employees in performing their duties, seeking help and solutions when they have problems in their work. When existing work can be done or completed properly then existing employees will feel satisfied and get a good performance assessment.

\section{REFERENCES}

[1]. A. Dale Timpe, 2002. Kinerja, (Jakarta: PT Gramedia)

[2]. Abelio Petrik dan Fransisca Andreani (2015), Analisa Pengaruh Gaya Kepemimpinan Transformasional Terhadap Kinerja Karyawan dengan Kepuasan Kerja sebagai Variabel Perantara di PT. Anugerah Baru Denpasar, Program Manajemen Bisnis, Program Studi Manajemen, Universitas Kristen Petra

[3]. Al-Hamdan, Z., Manojlovich, Milisa, PhD,R.N., C.C.R.N., \& Tanima, B., M.S. (2017). Jordanian nursing work environments, intent to stay, and job satisfaction. Journal of Nursing Scholarship, 49(1), 103-110.

[4]. Amin, M., Tatlah, I.A., \& Khan, A.M. (2013). Which leadership style to use ? An investigation of conducive and non-conducive leadership style(s) to fuculty job satisfaction. Internasional research Journal of Arts and Humanities, 41(41), 229-253.

[5]. As'ad, Moh., 2004, Teori Ilmu Sumber Daya Manusia, Psikologi Industri, Liberty, Yogyakarta.

[6]. Bateh, J. T. (2013). Leadership styles and faculty satisfaction in the state university system of florida (Order No. 3566772).

[7]. Bass. B.M. \& B. J. Avolio, 1990, Manual for the Multifactor Leadership Questionnaire, Palo Alto, CA: Consulting Psychologist Press 


\section{International Advanced Research Journal in Science, Engineering and Technology \\ ISO 3297:2007 Certified}

Vol. 5, Issue 8, August 2018

[8]. Bass, B. M, \& Riggio, R.E. (2005). Transformasional Leadership (2nd ed). England : Psychology Press

[9]. Bass, Bernard, M., Bruce, J.A., Dong, I.Y., and Yair, B. 2003. Preciding Unit Performance by Assesing Transformational and Transacsional Leadership. Journal of Applied Psychology, 2003, Vol. 88. No. 2. pp. 207-218.

[10]. Bai, J., Zhang, Q., Wang, Y., Yu, L., Pei, X., Cheng, L., \& Hsu, L. (2015). Work environment for chinese nurses in different types of ICUs: A multisite cross-sectional survey. Journal of Nursing Management, 23(4), 498-509.

[11]. Bernadin, J. H. \& Russell, J. E. (2000). Human resource management: An experimential approach. New York: Mc Graw Hill Companies.

[12]. Brown (2003) dalam Suhana, 2007. Menguji Pengaruh Perilaku Kepemimpinan pada Hubungan dan Tugas Terhadap Komitmen Organisasi.

[13]. Breevaart, et.al. (2014). Uncovering the underlying relationship between transformational leaders and followers' task performance. Journal of Personnel Psychology, 13(4), 194-203.

[14]. Campbell, T. M. (2016). Dean transformational and transactional leadership traits and faculty job satisfaction: A quantitative, non-experimental, correlational study (Order No. 10143691). Available from ProQuest Dissertations \& Theses Global. (1824661219).

[15]. Chi,H-K., Yeh, H-R., \& Yu, C.H. (2008). Teh Effects of Transformation Leadership, Organizational Culture, Job Satisfaction on the Organizational Performance in the Non-Profit Organizational Commitment. Journal of Business Strategies, 5(1),39-50.

[16]. Chia-Hao, C., \& Ting-Ya, H. (2018). The study of Employee's Job Stress, Happiness, and Job Performance - Taiwan Construction Industry Company for Example. International Journal of Organizational Innovation (Online), 10(3), 126-143.

[17]. Dasgupta, S., Papadimitrou, C., \& Vazirani,U. (2006). Algorithms. England: Cambridge University Press.

[18]. Dubrin, A.J. (2012). Leadership (Terjemahan e.d) Jakarta : Prenada Media

[19]. Doelhadi, E. M. 2001. Kerja dalam Dimensi Tinjauan Psikologis. Insan Jurnal Psikologi. Vol.3.

[20]. Frieder, R. E., Wang, G., \& Oh, I. (2018). Linking job-relevant personality traits, transformational leadership, and job performance via perceived meaningfulness at work: A moderated mediation model. Journal of Applied Psychology, 103(3), 324-333.

[21]. Heather Golm (2009) Examining the Relationship Between Transformational, Transactional, and Change-Oriented Leadership and Their Influence on Leadership Effectiveness, Submitted in partial fulfillment of the requirements for the degree of Doctor of Philosophy under the Executive Committee of The Graduate School of Arts and Sciences, Columbia University

[22]. Gouzali Saydam, (2000), Manajemen Sumber Daya Manusia (Human Resource) Suatu Pendekatan Mikro, Djanbatan, Jakarta

[23]. Hedlund Ann. Mattias Åteg. Ing-Marie Andersson. Gunnar Rosén. 2010. Assessing Motivation for Work Environment Improvements: Internal Consistency, Reliability and Factorial Structure. International Journal of Safety Research. pp. 145-151.

[24]. Huddleston, P. (2015). Measuring direct care nurses' and nurse leaders' perceptions of a healthy work environment within acute care settings (Order No. 3709734). Available from Health Management Database; Nursing \& Allied Health Database; ProQuest Dissertations \& Theses Global. (1700216555).

[25]. Heidjrachman dan S. Husnan, 2002, Manajemen Personalia dan Sumberdaya Manusia, edisi II, cetakan 12, (Yogyakarta, BPFE)

[26]. Hasibuan., Malayu S.P, 2007. Manajemen Sumber Daya Manusia: Dasar Kunci Keberhasilan (Jakarta: Cetakan 9, PT. Bumi Aksara)

[27]. Issah, M. (2013). The relationship between perceptions of fit and job satisfaction among administrative staff in a midwestern university (Order No. 3671386). Available from ProQuest Dissertations \& Theses Global. (1645769231).

[28]. Isham, A. 2004. Pengaruh Keadilan Prosedural, Kepuasan Kerja, dan Perilaku Anggota Organisasi Terhadap Kinerja Dosen Universitas Islam Negeri Syarif Hidayatullah Jakarta. Disertasi. Jakarta

[29]. Korkmaz, M. (2007). The effects of leadership styles on organizational health.Educational Research Quarterly, 30(3), 22-54

[30]. Luthans Fred. 2006, Perilaku Organisasi, edisi sepuluh, Yogyakarta: Penerbit Andi.

[31]. Mathis, Robert.L, \& John Jackson, 2006, Manajemen Sumber Daya Manusia. PT. Salemba Empat. Jakarta M

[32]. Malhotra, N., \& Dash, S (2011). Marketing Research An Applied Orientation (11 ed.). England. Pearson.

[33]. Mangkunegara, Anwar Prabu. 2001. Manajemen sumber daya manusia perusahaan, Bandung : Remaja Rosdakarya.

[34]. Negussie, N., \& Demissie, A. (2013). Relationship betwen leadership styles of nurse managers and nurse's job satisfaction in jimma university specialized hospital . Ethiopian Journal of Health Science, 23(1), 49-58.

[35]. Nawawi, H. 2010. Kepemimpinan Mengefektifkan Organisasi. Gadjah Mada University Press, Yogyakarta.

[36]. O’Leary, Elizabeth. 2001. Kepemimpinan. Edisi Pertama. Yogyakarta : Andi

[37]. Parr, Carter Min Z., Armenakis Achilles A., Field Hubert S., and Mossholder Kevin W. 2013. Transformational leadership, relationship quality, and employee performance during continuous incremental organizational change. Journal of Organizational

[38]. Pareke, F, Js., 2004, Kepemimpinan Transformasional dan Perilaku Kerja Bawahan: Sebuah Agenda Penelitian, Jurusan Manajemen Fakultas Ekonomi Universitas Bengkulu, Tidak Dipublikasikan.

[39]. Ross-Grant, L. (2016). Exploring the relationships between leadership styles and job satisfaction among employees of nonprofit organizations (Order No. 10111462). Available from ProQuest Dissertations \& Theses Global. (1798478720).

[40]. Robbins, Stephen P. 2008, Perilaku Organisasi, Edisi Bahasa Indonesia. Indeks Kelompok Gramedia, Jakarta

[41]. Riggio, R.E., 1990, Introduction to Industrial and Organization Psychology. Scott, Forestman and Company, London.

[42]. Rivai, Veithzal, 2006. Manajemen Sumber Daya Manusia untuk Perusahaan: dari Teori Ke Praktik, Edisi Pertama, Jakarta: Penerbit PT. Raja Grafindo Persada

[43]. Rojuaniah, 2017, Kepuasan Kerja Sebagai Pendorong Komitmen Organisasional Dan Organizational Citizenship Behavior (OCB), Jurnal Ekonomi, http://ejurnal.esaunggul.ac.id/index.php/Eko/article/view/2028

[44]. Sadasa, K. (2013). The Influence of organizational culture, leadership, job satisfaction towards teacher job performance. Indian Journal of Health and Wellbeing, 4 (9), 1637-1642.

[45]. Smith, Kendall, \& Hulin. (2004). Perilaku Organisasi (7 ed.). (Munandar, Penerj.) Jakarta : Erlangga

[46]. Sedarmayanti, 2009. Sumber Daya Manusia dan Produktivitas Kerja. Bandung: CV Mandar Maju

[47]. Siagian, S.P. 2004, Manajemen Sumber Daya Manusia (Jakarta: Bumi Aksara)

[48]. Simamora, H. 2004. Manajemen Sumber Daya Manusia, Edisi ke-3 (Yogyakarta: Bagian Penerbitan Sekolah Tinggi Ilmu Ekonomi YKPN

[49]. Sudarmanto. 2009. Kinerja dan Pengembangan Kompetensi SDM (Teori, Dimensi Pengukuran dan Implementasi dalam Organisasi). Yogyakarta : Pustaka Pelajar

[50]. Wagner, S. H. (2017). Exploring the structure of job satisfaction and its impact on the satisfaction-performance relationship. Journal of Organizational Psychology, 17(4), 90-101

[51]. Walumbwa, F. O., Avolio, B. J., \& Zhu, W. (2008). How Transformational Leadership weaves its influence on individual job performance : The role of identification and efficacy beliefs. Personnel Psychology, 61(4), 793-825.

[52]. Yukl, G.A,. 1998, Leadership in Organization, Second Edition, Englewood Clifs, Prentice-Hall, Inc, New Jersey.

[53]. Zaman, K., \& Yiing, L.H. (2009). The moderating effects of organizational culture on the relationships between organizationalcommitment and job satisfaction and performance. Leadership \& Organizational Development Journal, 30(1), 53-86.

[54]. Verdigets, F. L. (2008). Insights into leadership: The role of political skill, social skill, and self-monitoring in mediating the relationship between transformational leadership and job performance (Order No. 3333165). Available from ProQuest Dissertations \& Theses Global. (304689158). 